\title{
6: 112301320-112089178
}

National Cancer Institute

\section{Source}

National Cancer Institute. 6:112301320-112089178. NCI Thesaurus. Code C42345.

Physical location of FYN_Gene 